\title{
Synthesis and Electrochemical Characterizations of 7- Ferrocenycarbonyloxy-1-heptanethiol on Gold Substrates
}

\author{
M. M. Rahman ${ }^{1}$, K. J. Oh, and I. C. Jeon \\ Laboratory of Interface and Surface Science, Department of Chemistry, Chonbuk National \\ University, Chonju 561-756, Korea
}

Received 21 December 2008, accepted in final revised form 4 April 2009

\begin{abstract}
The 7-ferrocenycarbonyloxy-1-heptanethiol $\left(\mathrm{FcCO}_{2} \mathrm{C}_{7} \mathrm{SH}\right)$ is synthesized using ferrocene carboxylic acid, 1,6-fibromohexane, and NaS, which is confirmed and separated by FT-IR, ${ }^{1} \mathrm{H}$ NMR, and column chromatography. The basic redox (interfacial) properties are also studied of the self-assembled monolayers (SAMs) formed with this synthesized compound on polycrystalline gold electrode by Electrochemical Quartz Crystal Microbalance (EQCM). The $\mathrm{FcCO}_{2} \mathrm{C}_{7} \mathrm{SH}$ on gold acts as a barrier for the electron transfer between the gold electrode and $\mathrm{HClO}_{4}$ in solutions and as a mediator for the reduction of $\mathrm{Fe}^{3+}$ in solution. The frequency change (interfacial mass change) on the gold electrode surface is observed during the redox of ferrocenyl groups.
\end{abstract}

Keywords: 7-Ferrocenycarbonyloxy-1-heptanethiol; Self-Assembled Monolayers; EQCM; Peak current; Modified gold electrode.

(C) 2009 JSR Publications. ISSN: 2070-0237 (Print); 2070-0245 (Online). All rights reserved.

DOI: $10.3329 /$ jsr.v1i2.1746

\section{Introduction}

Self-assembled monolayers (SAMs) based on alkane thiols $\left(\mathrm{CH}_{3}\left(\mathrm{CH}_{2}\right)_{n} \mathrm{SH}\right)$ represent a versatile means for the modification of surfaces [1-3]. The SAM can be tailored to have a specific thickness or to present, at the SAM/solution interface, a given physical (such as hydrophobicity or hydrophilicity) or chemical property (for example a specific chemical group able to react with or bind to another chemical entity). Supramolecular structures that might undergo redox conversions are relevant to molecular biosensors and other electronic devices of the future [4]. Examples of such systems in this diverse field of research include redox-active self-assembled monolayers (SAMs), redox-modulated recognition sensors, redox-switchable membranes etc. Commonly used organic compounds for SAMs include various derivatives containing a mercapto group. The selfassembly method has been recognized as one of the most attractive approaches to creating well-defined functional molecular layers on solid surfaces [5]. The most widely studied self-assembly system is the chemisorption of sulfur derivatives (i.e. thiols and disulfides)

\footnotetext{
${ }^{1}$ Corresponding author: mmrahman@chonbuk.ac.kr
} 
on gold [6-12]. Many scientists have been reported the electrochemical characteristics of ferrocenyl-alkanethiol self-assembled monolayers on gold [13-24].

Ferrocene $(\mathrm{Fc})$-terminated alkanethiols occupy a highly important place in the field of SAM-forming substances because of their potential applications in electrochemical biosensors, heterogeneous catalysis, etc. [25-36]. EQCM has been studied at the gold electrode modified with $\mathrm{FcCO}_{2} \mathrm{C}_{7} \mathrm{SH}$ monolayer in solution containing other redox species $\mathrm{K}_{3} \mathrm{Fe}(\mathrm{CN})_{6}$ to monitor the mass change (frequency in $\mathrm{Hz}$ ) during the potential cycling. The $\mathrm{FcCO}_{2} \mathrm{C}_{7} \mathrm{SH} \mathrm{SAM}$ on gold acts as a mediator for the electron transfer in electrochemical solutions [37]. It has been shown that the redox properties of a Fc group depend both on the length and molecular structure of the chain. For instance, introduction of an ester group with a considerable dipole moment into the chain may perturb the monolayer packing, and the interfacial orientation of the redox-active moiety due to the dipole-dipole interactions [38]. However, as far as we know, Fc-terminated alkylthiols containing an ester group somewhere in the middle of the $\mathrm{C}_{12}-\mathrm{C}_{13}$ chain have not been synthesized or investigated. Our main attention is to synthesize new SAM-forming 7ferrocenycarbonyloxy-1-heptanethiol compound and study its electrochemical interfacial properties on polycrystalline gold substrates.

\section{Experimental}

Sodium perchlorate monohydrate (98\%), perchloric acid (70\%), ferrocene carboxylic acid (97\%), 1,6-dibromohexane (96\%), $\mathrm{CH}_{3} \mathrm{CN}, \mathrm{NaS}, \mathrm{Fe}\left(\mathrm{ClO}_{4}\right)_{3}(98 \%)$ and tetrahydrofuran (THF) were purchased from Aldrich Chemical Company, and used without further purification. The voltammetry performed in this study employed a conventional threeelectrode cell with a polycrystalline gold working electrode, Pt counter electrode and $\mathrm{Ag} / \mathrm{AgCl}$ (satd. $\mathrm{KCl}$ ) as the reference. The commercial potentiostat, an electrochemical quartz crystal microbalance (EQCM, Shin EQCN1000, Korea) was used for all electrochemical investigations. Electrodes were gold on $9 \mathrm{MHz}$ AT-cut quartz crystals, which were usually used for EQCM. The mass sensitivity of $9 \mathrm{MHz}$ quartz crystals is calculated to be $5.46 \mathrm{ng} \mathrm{cm}^{-2} \mathrm{~Hz}^{-1}$. The gold used was $99.99 \%$ pure and vacuum (ca.1 $1 \times 10^{-7}$ Torr) deposited on $5 \mathrm{~nm}$ Ti underlayer to form a Au-layer of ca. $100 \mathrm{~nm}$ thickness by Thermal and E-beam evaporation system (HVEB 200, Hanvac, Korea).

All electrodes were pretreated and polishing by repeated cycling $\left(50 \mathrm{mVs}^{-1}\right)$ of the electrode in $0.1 \mathrm{M} \mathrm{H}_{2} \mathrm{SO}_{4}$ between the system's $\mathrm{O}_{2}$ and $\mathrm{H}_{2}$ evolution potentials, until a reproducible voltammogram with well defined features was obtained. The gold evaporated crystals were cleaned thoroughly by Piranha solution for 10.0 mins (a mixture of $98 \% \mathrm{H}_{2} \mathrm{SO}_{4}$ and $30 \% \mathrm{H}_{2} \mathrm{O}_{2}$ at $2: 1 \mathrm{v} / \mathrm{v}$ ) [Caution! Piranha solution is a very strong oxidizing agent and reacts violently with organic compounds. Freshly prepared piranha solution should be handled with extreme care]. The average roughness factor and surface areas calculated for lab made polycrystalline gold electrode were $1.2( \pm 0.10)$ and 0.26 $\mathrm{cm}^{2}$, respectively. To prepare the electrochemical and electrolyte solutions for electrochemical observation, deionize water (resistivity, $>18.2 \mathrm{M} \Omega . \mathrm{cm}$ ) is used. The 7- 
ferrocenycarbonyloxy-1-heptanethiol $\left(\mathrm{FcCO}_{2}\left(\mathrm{CH}_{2}\right)_{7} \mathrm{SH}\right)$ is synthesized according to reactions (scheme-1) using ferrocene carboxylic acid (97\%) and 1,6-dibromohexane (98\%). The cleaned gold polycrystalline electrode was modified by dip-treatment in an ethanol solution containing $\mathrm{FcCO}_{2} \mathrm{C}_{7} \mathrm{SH}$ at 24.0 hours. After modification of the substrates, it was rinsed thoroughly with pure ethanol and then dried with stream of $\mathrm{N}_{2}$. The $\mathrm{FcCO}_{2} \mathrm{C}_{7} \mathrm{SH}$ monolayer modified crystal was monitored with EQCM. IR spectra (4000$200 \mathrm{~cm}^{-1}$ ) were recorded by a FT-IR spectrometer (AVATAR 330, Thermo Nicolet. USA) as a $\mathrm{KBr}$ disc. The ${ }^{1} \mathrm{H}$ NMR spectra were recorded in $\mathrm{CDCl}_{3}(\mathrm{ppm})$ on the $400 \mathrm{MHz} \mathrm{NMR}$ Instrument (Japan).

\section{Synthesis procedure of compound $\mathrm{FcCOO}\left(\mathrm{CH}_{2}\right)_{7} \mathrm{SH}$ (Scheme-1)}

(1) Ferrocene carboxylic acid (500 mg, $2.17 \mathrm{mmol}), 1,7$ Dibromoheptane (700 mg, $2.71 \mathrm{mmol})$ and $\mathrm{NaOH}(80 \mathrm{mg}, 2.20 \mathrm{mmol})$ in dried $\mathrm{CH}_{3} \mathrm{CN}(20.0 \mathrm{ml})$ were reacted (stirred by magnetic stirring bar) in oil bath (ca. $40.0^{\circ} \mathrm{C}$ ) under argon atmosphere to produce compound A $\left[\mathrm{FcCO}_{2}\left(\mathrm{CH}_{2}\right)_{7} \mathrm{Br}\right]$. Reacted solvents were removed using rotary vacuum evaporator. The residue was purified and separated by column chromatography.

${ }^{1} H$ NMR data for compound $A$ : Yield $62 \%,{ }^{1} \mathrm{H}$ NMR $\delta(\mathrm{ppm}), \mathrm{CDCl}_{3}: 1.80-1.85(14 \mathrm{H}$, $\mathrm{m}), 3.40(2 \mathrm{H}, \mathrm{t}, \mathrm{J}=8 \mathrm{~Hz}), 4.12-4.22(7 \mathrm{H}, \mathrm{m}), 4.39(2 \mathrm{H}, \mathrm{s}), 4.80(2 \mathrm{H}, \mathrm{s})$.

(2) To make solution with compound A (300 mg, $0.73 \mathrm{mmol})$ and $\mathrm{NaSH}(200 \mathrm{mg}$, $0.36 \mathrm{mmol})$ in dried THF $(30 \mathrm{ml})$ was stirred by magnetic stirring bar in oil bath (ca. 40.0 ${ }^{\circ} \mathrm{C}$ ) for 24 hours under argon atmospheres. The reaction solvent was removed and residue was dissolved in diethyl ether $(30.0 \mathrm{ml})$ and water $(10.0 \mathrm{ml})$. Ether layer was selected and dried with anhydrous $\mathrm{MgSO}_{4}$. Ether layer was removed with the rotary vacuum evaporator. The residue was purified and separated with column chromatography.

${ }^{1} \mathrm{H}$ NMR data for final product B: Yellow powder, yield $0.424 \mathrm{~g}, 60 \%,{ }^{1} \mathrm{H}$ NMR $\delta$ (ppm), $\mathrm{CDCl}_{3}: 1.42-1.72(14 \mathrm{H}, \mathrm{m}), 1.56(1 \mathrm{H}, \mathrm{s}), 2.68(2 \mathrm{H}, \mathrm{t}, \mathrm{J}=8 \mathrm{~Hz}), 4.20-4.22(7 \mathrm{H}, \mathrm{m})$, $4.39(2 \mathrm{H}, \mathrm{s}), 4.80(2 \mathrm{H}, \mathrm{s})$.

The final product $\left(\mathrm{B}, \mathrm{FeCO}_{2} \mathrm{C}_{7} \mathrm{SH}\right)$ is detected in the FT-IR spectrum by a $-\mathrm{CO}$ (ester) stretching mode at $1702 \mathrm{~cm}^{-1}, \mathrm{C}-\mathrm{H}$ stretching (pentene) at $3020 \mathrm{~cm}^{-1},-\mathrm{SH}$ (mercaptans) at $2550 \mathrm{~cm}^{-1}$ alkane chain $\left(-\mathrm{CH}_{2^{-}}\right) \mathrm{C}-\mathrm{H}$ stretching at $2852 \mathrm{~cm}^{-1}$ and bending at $1456 \mathrm{~cm}^{-1}$.

\section{Results and Discussion}

Investigations of the chemical modification of metal and semiconductor electrode surfaces by adsorption of functional molecules have been carried out by synthesized ferrocene alkane thiol. Considering the foregoing, we synthesized the 7-ferrocenycarbonyloxy-1heptanethiol $\left[\mathrm{FcCOO}\left(\mathrm{CH}_{2}\right)_{7} \mathrm{SH}\right.$, shortly $\left.\mathrm{FcCO}_{2} \mathrm{C}_{7} \mathrm{SH}\right]$ compound. The synthetic steps are presented in Scheme 1. In step-1, ferrocene carboxylic acid (97\%) reacted with 1,7 dibromoheptane in presence of $\mathrm{CH}_{3} \mathrm{CN}, \mathrm{NaOH}$ under $40.0{ }^{\circ} \mathrm{C}$ (in argon environment) for 24 hours to produce product A (62\% yield). Finally, the Fc-terminated with thiol derivatized compound $\mathrm{B}$ is obtained using $\mathrm{NaS}$, THF in ca. $40.0{ }^{\circ} \mathrm{C}$ (in argon 
environment) for 24 hours. We succeeded in obtaining compound product $\mathrm{B}$ $\left[\mathrm{FcCO}_{2}\left(\mathrm{CH}_{2}\right)_{7} \mathrm{SH}\right]$ in $60 \%$ yields.

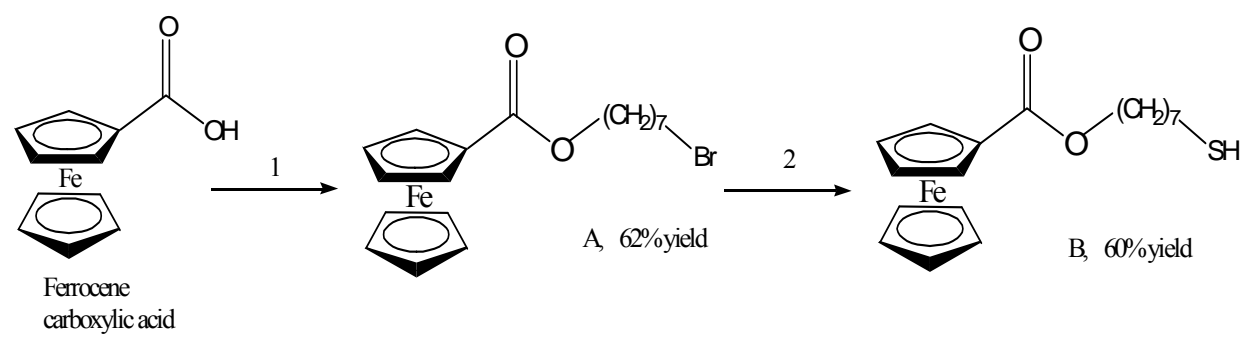

Scheme 1. Reagents and conditions: (1) Dibromoheptane, $\mathrm{NaOH}, \mathrm{CH}_{3} \mathrm{CN}, 40.0{ }^{\circ} \mathrm{C}, 24$ hours, argon environment, $87 \%$ yield (2) $\mathrm{NaSH}, \mathrm{THF}, 40.0{ }^{\circ} \mathrm{C}, 24$ hours, argon environment, $42 \%$ yield.

Following the synthesis, basic self-assembling and electrochemical features of the monolayers formed by compound $\mathrm{B}\left(\mathrm{FcCO}_{2} \mathrm{C}_{7} \mathrm{SH}\right)$ on gold were studied by cyclic voltammetry $(\mathrm{CV})$. For electrochemical experiments, monolayers were obtained via selfassembly of the compounds for $24 \mathrm{~h}$ from $2.0 \mathrm{mM}$ ethanolic solutions on a pre-treated polycrystalline $\mathrm{Au}$ surface. In anaerobic $1.0 \mathrm{M} \mathrm{NaClO}_{4}$ at $25.0{ }^{\circ} \mathrm{C}$, the $\mathrm{CV}$ curves of the SAMs exhibited clearly expressed oxidation-reduction peaks of the $\mathrm{Fc}^{+} / \mathrm{Fc}^{\circ}$ couple as shown in Fig. 1. This curve served to determine the formal redox potentials $E^{\circ \prime}(+0.634 \mathrm{~V})$ and surface concentrations (surface coverage, $\Gamma=2.67 \times 10^{-10} \mathrm{~mole}^{-2}$ ) of compound $\mathrm{FcCO}_{2} \mathrm{C}_{7} \mathrm{SH}$ in the monolayers on gold substrates.
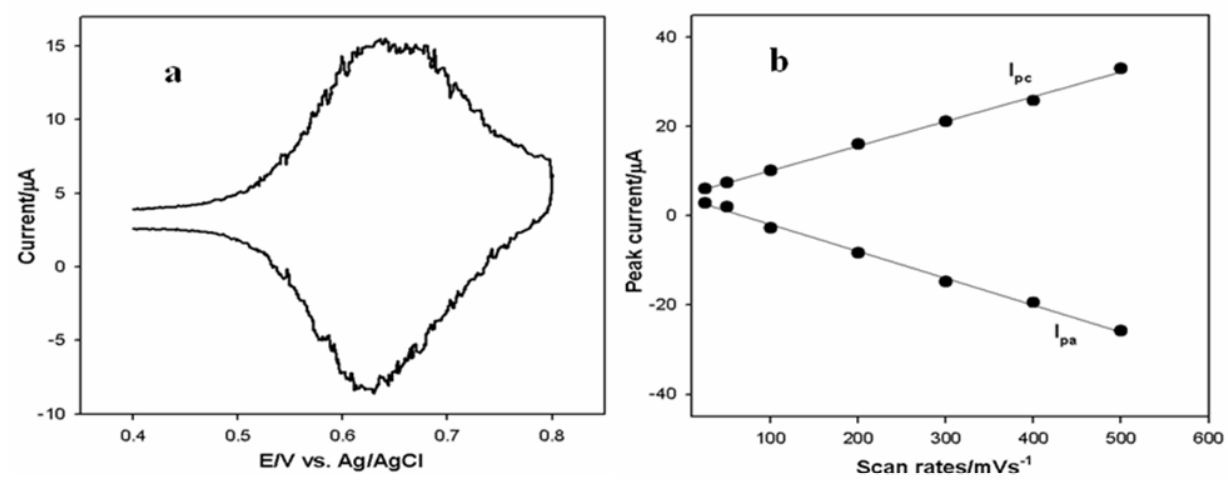

Fig. 1. (a) Cyclic voltammetric curves of the gold working electrode modified by compound recorded in $1.0 \mathrm{M}$ $\mathrm{NaClO}_{4}$ solution at $25^{\circ} \mathrm{C}$ and a scan rate of $20 \mathrm{mV} / \mathrm{s}$. (b) Anodic $\left(I_{\mathrm{pa}}\right)$ and cathodic peak $\left(I_{\mathrm{pc}}\right)$ current showing the dependence on the scan rates.

In an effort to study a well-known degradation of the Fc-terminated monolayers in aqueous media [39], a decrease of the electrochemically determined $\Gamma$ after a particular 
time of $E$ cycling over the $E$ scan range from $E^{\circ \prime}(+300 \mathrm{mV})$ to $E^{\circ \prime}(+1000 \mathrm{mV})$ was taken to be a measure of the monolayer stability. The later results indicate the exceptional stability of the $\mathrm{SAMs}$ of $\mathrm{FcCO}_{2} \mathrm{C}_{7} \mathrm{SH}$ in the $\mathrm{NaClO}_{4}$ solution. Another interfacial feature of the monolayers $\mathrm{FcCO}_{2} \mathrm{C}_{7} \mathrm{SH}$ was derived from the electrochemical experiments performed at relatively low scan rates. The slope of the $\mathrm{CV}$ anodic $\left(I_{\mathrm{pa}}\right)$ and cathodic $\left(I_{\mathrm{pc}}\right)$ peak currents versus scan rates reflects the interaction between attached molecules in Fig. 1(b). From these slopes the interaction parameters were calculated [40, 41]. For compound, $\mathrm{FcCO}_{2} \mathrm{C}_{7} \mathrm{SH}$ the obtained interaction parameters were of opposite signs, $-0.371 \times 10^{10}$ and $0.377 \times 10^{10} \mathrm{~cm}^{2} / \mathrm{mol}$, respectively, indicating repulsion between the $\mathrm{Fc}-$ centre in the monolayer of $\mathrm{FcCO}_{2} \mathrm{C}_{7} \mathrm{SH}$. It might be speculated that, in the case of this compound, the presence of a $\mathrm{C}=\mathrm{O}$ group close to the $\mathrm{Fc}$ ring prevents the effective neutralization of $\mathrm{Fc}^{+}$by counter ions, resulting in repulsion between attached molecules.

EQCM response of the $\mathrm{FcCO}_{2} \mathrm{C}_{7} \mathrm{SH}$-modified gold electrode in $\mathrm{Fe}^{3+}+\mathrm{HClO}_{4}$ solution is studied at room conditions. Fig. 2(a) shows $\mathrm{CVs}$ of the $\mathrm{FcCO}_{2} \mathrm{C}_{7} \mathrm{SH}$-modified gold electrode and an unmodified gold electrode in $1.0 \mathrm{M} \mathrm{HClO}_{4}$ solution containing $1.0 \mathrm{mM}$ $\mathrm{Fe}\left(\mathrm{ClO}_{4}\right)_{3}$ with a sweep rate of $50 \mathrm{mV} \mathrm{s}^{-1}$. Reversible redox peaks were observed in 1.0 $\mathrm{mM} \mathrm{Fe}\left(\mathrm{ClO}_{4}\right)_{3}+1.0 \mathrm{M} \mathrm{HClO}_{4}$ solution at the unmodified gold electrode around +650 $\mathrm{mV}$. At the modified gold electrode, however, these high current peaks were not observed, showing that the direct electron transfer between $\mathrm{Fe}^{3+}$ and the gold electrode surface was blocked by the $\mathrm{FcCO}_{2} \mathrm{C}_{7} \mathrm{SH}$ monolayer. In addition to a pair of peaks around $+590 \mathrm{mV}$, a relatively large cathodic current peak was observed around $+500 \mathrm{mV}$. This peak current increased linearly with the concentration of $\mathrm{Fe}^{3+}$ in solution, and became larger at a slower sweep rate. The peak potential was not affected by the sweep rate. The compact surface monolayer inhibits the direct electron transfer between the electrode and $\mathrm{Fe}^{3+} / \mathrm{Fe}^{2+}$ in solution, and that the surface $\mathrm{FcCO}_{2} \mathrm{C}_{7} \mathrm{SH}$ monolayer acts as a mediator for the electron transfer from the electrode to $\mathrm{Fe}^{3+}$ in solution [19].
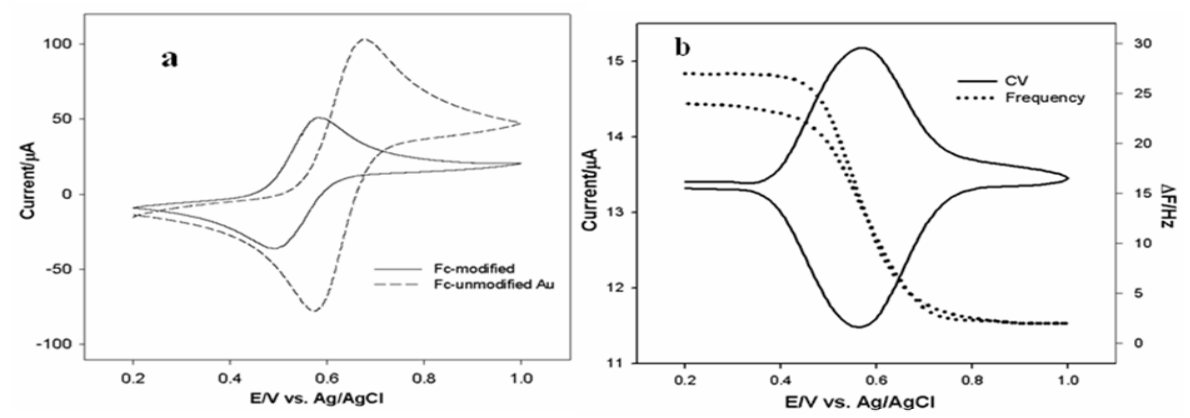

Fig. 2. (a) Cyclic voltammograms of a gold electrode modified and unmodified with $\mathrm{FcCO}_{2} \mathrm{C}_{7} \mathrm{SH}$ molecule in $1.0 \mathrm{M} \mathrm{HClO}_{4}$ and $1.0 \mathrm{mM} \mathrm{Fe}\left(\mathrm{ClO}_{4}\right)_{3}$. Sweep rate $50 \mathrm{mV} \mathrm{s}^{-1}$. (b) EQCM (CV and frequency change) of the $\mathrm{FcCO}_{2} \mathrm{C}_{7} \mathrm{SH}$ modified gold electrode recorded simultaneously with potential cycling.

Fig. 2 shows the frequency change recorded simultaneously with the measurement of the $\mathrm{CV}$ at the modified electrode. It is measured that the frequency change is due to the redox 
reaction of the ferrocene moiety. Since the total frequency change was larger than that in $\mathrm{HClO}_{4}$ solution without $\mathrm{Fe}^{3+}$, the actual frequency value in $\mathrm{Fe}^{3+}$-containing solution may not be the same as that obtained in $\mathrm{Fe}^{3+}$-free solution. Fig. 2(b) shows the potential dependence of the calculated current. This is very similar to the CV obtained in $1.0 \mathrm{M}$ $\mathrm{HClO}_{4}$ solution without $\mathrm{Fe}^{3+}$, although one must note that the absolute value of the current may not be accurate because of the ambiguity of electrode surface. Thus, this treatment enables one to separate the current due to the redox of ferrocene moieties from the measured current. These results show clearly that the redox of the ferrocene moiety occurs as if there is no $\mathrm{Fe}^{3+}$ in solution and the mediation reaction proceeds without ion pair formation. Thus, around $+570 \mathrm{mV}$, reduction of the ferricenium cation takes place as:

$$
\mathrm{Fc}^{+} \mathrm{ClO}_{4}^{-}+\mathrm{e}^{-} \rightarrow \mathrm{Fc}+\mathrm{ClO}_{4}^{-}
$$

and $\mathrm{ClO}_{4}^{-}$desorbs from the monolayer. Then ferrocene reduces $\mathrm{Fe}^{3+}$ in solution and ferrocene is converted to ferricenium cation which accepts an electron from the electrode as soon as it is formed:

$$
\begin{aligned}
& \mathrm{Fc}+\mathrm{Fe}^{3+} \rightarrow \mathrm{Fc}^{+}+\mathrm{Fe}^{2+} \\
& \mathrm{Fc}^{+}+\mathrm{e}^{-} \rightarrow \mathrm{Fc}
\end{aligned}
$$

The rate of mediation process is limited by the diffusion of $\mathrm{Fe}^{3+}$. In contrast, the total frequency change, ca. $25.0 \mathrm{~Hz}$, was larger than that observed in solution without $\mathrm{Fe}^{3+}$ cation. One possible reason why the frequency change was larger in solution containing $\mathrm{Fe}^{3+}$ cation is that the $\mathrm{Fe}^{3+}$ cation is adsorbed on and desorbed from the modified surface during the redox of the ferrocene moiety. When the ion pairs $\left(\mathrm{Fc}^{+} \mathrm{ClO}_{4}^{-}\right)$were formed on the modified surface in the oxidation process, $\mathrm{Fe}^{3+}$ cations in electrolyte solution may approach and adsorb on the $\mathrm{ClO}_{4}^{-}$sites of ion pairs $\left(\mathrm{Fc}^{+} \mathrm{ClO}_{4}{ }^{-}\right)$. Thus, the weight increase and, therefore, the frequency decrease are much more than those in $\mathrm{HClO}_{4}$ solution without $\mathrm{Fe}^{3+}$. Since both the $\mathrm{ClO}_{4}^{-}$anion and the $\mathrm{Fe}^{3+}$ cation are removed from the monolayer in the reduction process, a larger frequency change should be observed. After the measurement in $\mathrm{Fe}^{3+}+\mathrm{HClO}_{4}$ solution, the total frequency change of this electrode returns to the initial value obtained in $\mathrm{HClO}_{4}$ solution without $\mathrm{Fe}^{3+}$ cation.

\section{Conclusions}

$\mathrm{FcCO}_{2} \mathrm{C}_{7} \mathrm{SH}$ is synthesized and studied self-assembled monolayer on gold surface. Electrochemical current responses were complicated because the observed currents were due to the redox of both the ferrocenyl group immobilized on gold and others in electrolyte solutions. The interfacial electrochemical change on the gold electrode surface observed during the redox of ferrocenyl groups. In presence of carbonyl group in $\mathrm{FcCO}_{2} \mathrm{C}_{7} \mathrm{SH}$ compound, the $\mathrm{Fc}$ ring neutralized of its $\mathrm{Fc}^{+}$by counter ions. We have carried out the EQCM study at the gold electrode modified with $\mathrm{FcCO}_{2} \mathrm{C}_{7} \mathrm{SH}$ monolayer 
in solution containing other redox species $\left(\mathrm{Fe}(\mathrm{CN})_{6}{ }^{4-/ 3-}\right.$ or $\left.\mathrm{Fe}^{2+/ 3+}\right)$ to monitor the mass transport during the potential cycling. It was found that the mass transport occurred by the adsorption and desorption of $\mathrm{ClO}_{4}$ anion on the electrode surface as a result of oxidation and reduction respectively of the Fc group. Although the CVs observed in the solution containing $\mathrm{Fe}(\mathrm{CN})_{6}{ }^{4-}$ and $\mathrm{Fe}^{3+}$ are complicated, it is possible to separate the current component due to the redox reaction of $\mathrm{Fc}$ groups from that of others by the comparison of the measured $\mathrm{CV}$ and the $\mathrm{CV}$ calculated from the frequency change.

\section{References}

1. A. Ulman An Introduction to Ultrathin Organic Films from Langmuir-Blodgett to SelfAssembly, Academic Press, San Diego, CA (1991).

2. L.H. Dubois and R.G. Nuzzo Annu, Rev. Phys. Chem. 43, 437 (1992).

3. H. O. Finklea, In: A.J. Bard, I. Rubinstein, Editors, Electroanalytical Chemistry. A Series of Advances 19, Marcel Dekker, New York (1996) 109.

4. R. M. Crooks and A. J. Ricco, Acc. Chem. Res. 31, 219 (1998). doi:10.1021/ar970246h

5. A. Ulman. An Introduction to Ultrathin Organic Films from Langmuir-Blodgett to SelfAssembly (Academic Press, New York, 1991).

6. R. G. Nuzzo and D. L. Allara, J. Am. Chem. Soc. 105, 4481 (1983). doi:10.1021/ja00351a063

7. M. D. Porter, T. B. Bright, and D. L. Allara, C. E. D. Chidsey, J. Am. Chem. Soc. 109, 3559 (1987). doi:10.1021/ja00246a011

8. H. O. Finklea, S. Avery, M. Lynch, and T. Furtsch, Langmuir 3, 409 (1987). doi:10.1021/la00075a024

9. C. D. Bain, E. B. Troughton, Y. T. Tao, J. Evall, G. M. Whitesides, and R. G. Nuzzo, J. Am. Chem. Soc. 111, 321 (1989). doi:10.1021/ja00183a049

10. M. M. Walczak, C. Chung, S. M. Stole, C. L. Widrig, and M. D. Porter, J. Am. Chem. Soc. 113, 2370 (1991). doi:10.1021/ja00007a004

11. C. A. Widrig, C. Chung, and M. D. Porter, J. Electroanal. Chem. 310, 335 (1991). doi:10.1016/0022-0728(91)85271-P

12. C. D. Bain, E. B. Troughton, and G. M. Whitesides, J. Am. Chem. Soc. 111, 7155 (1989). doi:10.1021/ja00200a039

13. C. E. D. Chidsey, C. R. Betozi, T. M. Putvinski, and A. M. Mujsce, J. Am. Chem. Soc. 112, 4301 (1990). doi:10.1021/ja00167a028

14. K. Uosaki, Y. Sato, and H. Kita, Langmuir 7, 1510 (1991). doi:10.1021/1a00055a038

15. J. J. Hickman, D. Ofer, C. Zou, M. S. Wrighton, P. E. Laibinis, and G. M. Whitesides, J. Am. Chem. Soc. 113, 1128 (1991). doi:10.1021/ja00004a010

16. G. K. Rowe and S. E. Creager, Langmuir 7, 2307 (1991). doi:10.1021/la00058a055

17. D. M. Collard and M. A. Fox, Langmuir 7, 1192 (1991). doi:10.1021/la00054a029

18. K. Shimazu, I. Yagi, Y. Sato, and K. Uosaki, Langmuir 8, 1385 (1992). doi:10.1021/la00041a023

19. Y. Sato, H. Itoigawa, and K. Uosaki, Bull. Chem. Soc. Jpn. 66, 1032 (1993). doi:10.1246/bcsj.66.1032

20. Y. Sato, B. L. Frey, R. M. Corn, and K. Uosaki, Bull. Chem. Soc. Jpn. 67, 21 (1994). doi:10.1246/bcsj.67.21

21. K. Shimazu, I. Yagi, Y. Sato, and K. Uosaki, J. Electroanal. Chem. 372, 117 (1994). doi:10.1016/0022-0728(94)03296-3

22. T. Ohtsuka, Y. Sato, and K. Uosaki, Langmuir 10, 3658 (1994). doi:10.1021/la00022a045

23. K. Shimazu, S. Ye, Y. Sato, and K. Uosaki, J. Electroanal. Chem. 375, 409 (1994). doi:10.1016/0022-0728(94)03601-2

24. G. K. Rowe and S. E. Creager, Langmuir 10, 1186 (1994). doi:10.1021/la00016a036 
25. J. D. Carr, L. Lambert, D. E. Hibbs, M. B. Hursthouse, K. M. A. Malik, and J. H. R. Tucker, Chem. Commun. 1649 (1997). doi:10.1039/a703183a

26. J. D. Carr, S. J. Coles, W. W. Hassan, M. B. Hursthouse, K. M. A. Malik, and J. H. R. Tucker, J. Chem. Soc., Dalton Trans. 57 (1999). doi:10.1039/a807453d

27. M. Lahav, E. Katz, and I. Willner, Electroanalysis 10,1159 (1998). doi:10.1002/(SICI)1521-4109(199811)10:17<1159::AID-ELAN1159>3.0.CO;2-L

28. V. Razumas, J. Kulys, M. Knichel, H. D. Wiemhöfer, and W. Göpel, Electroanalysis 5, 399 (1993). doi:10.1002/elan.1140050505

29. J. J. Sumner, K. S. Weber, L. A. Hockett, and S. E. Creager, J. Phys. Chem. B 104, 7449 (2000). doi:10.1021/jp000992v

30. S. Sek, A. Misicka, and R. Bilewicz, J. Phys. Chem. B 104, 5399 (2000). doi:10.1021/jp000376z

31. C. J. Yu, Y. Chong, J. F. Kayyem, and M. Gozin, J. Org. Chem. 64 (1999) 2070. doi:10.1021/jo982392m

32. B. S. Gallardo, V. K. Gupta, F. D. Eagerton, L. I. Jong, V. S. Craig, R. R. Shah, and N. L. Abbott, Science 283, 57 (1999). doi:10.1126/science.283.5398.57

33. C. M. Casado, I. Cuadrado, B. Alonso, M. Moran, and J. Losada, J. Electroanal. Chem. 463, 87 (1999). doi:10.1016/S0022-0728(98)00446-X

34. M. W. J. Beulen, F. C. J. M. V. Veggel, and D. N. Reinhoudt, Chem. Commun. 503 (1999). doi:10.1039/a809790i

35. O. Clot and M. O. Wolf, Langmuir 15, 8549 (1999). doi:10.1021/la990547v

36. D. Butkus, J. Tauraite, Z. Barauskas, V. Talaikyte, and V. Razumas, J. Chem. Res. 8, 722 (1998). doi:10.1039/a804318c

37. M. M. Rahman and I. C. Jeon, J. Organomet. Chem. 691, 5648 (2006). doi:10.1016/j.jorganchem.2006.09.014

38. A. Ulman, Chem. Rev. 96, 1533 (1996). doi:10.1021/cr9502357

39. H. O. Finklea, In: A.J. Bard, I. Rubinstein, Editors, Electroanalytical Chemistry, Marcel Dekker, New York (1996) 108.

40. A. P. Brown and F. C. Anson, Anal. Chem. 49, 1589 (1977). doi:10.1021/ac50019a033

41. H. Ju and D. Leech, Phys. Chem. Chem. Phys. 1, 1549 (1999). doi:10.1039/a809754b

42. M. M. Rahman and I. C. Jeon, Turk. J. Chem. 31, 17 (2007). 